\title{
Organoid and Primary Epithelial Cultures of Human Prostate Show the Key Role of the Epithelial-to-Mesenchymal Transition in Generation of Tissue-Specific Stromal Cells
}

\author{
V. M. Ryabov ${ }^{a}$, A. O. Georgieva ${ }^{b}$, M. A. Voskresensky ${ }^{c}$, B. K. Komyakov ${ }^{c}$, O. V. Rogoza ${ }^{d}$, R. V. Grozov ${ }^{d}$, \\ Ya. G. Murazove, D. G. Prokhorov ${ }^{\text {, and B. V. Popov }}$, * \\ ${ }^{a}$ Institute of Cytology, Russian Academy of Sciences, St. Petersburg, 194064 Russia \\ ${ }^{b}$ ITMO University, St. Petersburg, 197101 Russia \\ ${ }^{c}$ City Multidisciplinary Hospital No. 2, Ministry of Health of the Russian Federation, St. Petersburg, 194354 Russia \\ ${ }^{d}$ Almazov National Medical Research Center, Ministry of Health of the Russian Federation, St. Petersburg, 197341 Russia \\ e Petrov National Medical Research Center of Oncology, Ministry of Health of the Russian Federation, \\ St. Petersburg, 197758 Russia \\ ${ }^{f}$ Granov Russian Scientific Center for Radiology and Surgical Technologies, Ministry of Health of the Russian Federation, \\ St. Petersburg, 197758 Russia \\ *e-mail: borisvp478@gmail.com
}

Received April 4, 2021; revised April 26, 2021; accepted April 28, 2021

\begin{abstract}
The prostate gland (PG) is a small organ in the male reproductive system that is currently the focus of biomedical research due to its leading position in morbidity and mortality from the tissue-specific cancer prostate cancer (PC). The PG epithelium, which undergoes a cancerous transformation, is formed and functions under the control of androgens. At the beginning of the disease, epithelial cells produce an androgen receptor (AR) and are sensitive to androgen-deprivation therapy. However, such therapy inevitably leads to the transition of the disease to the castration-resistant prostate cancer (CRPC), which manifests itself in metastasis and rapid mortality. In CRPC, the cells of the prostate epithelium change their phenotype, that may be associated with AR mutation and loss the sensitivity to specific therapy. The mechanism of PG phenotypic transformation may be hidden in the interaction and formation of the stromal and epithelial cells, which are evident during the establishment of the primary cultures. The aim of this study was to investigate the generation of human PG stromal cells in primary stromal and organoid cultures. We found that, in contrast to the rapid appearance and formation of a homogeneous population of mesenchymal cells in primary stromal cultures of most tissues, human PG cell cultures are formed initially from epithelial cells. They appear in the second week of cultivation and produce cytokeratins (CKs). A homogeneous population of mesenchymal cells producing vimentin is formed only at the end of the fourth week of cultivation. It is accompanied by the disappearance of epithelial cells. At the same time, some epithelial cells simultaneously produce CKs and vimentin. In PG organoid cultures, there is often a concomitant growth of epithelial, but not mesenchymal, cells on culture plastic. During the cultivation of epithelial cells arising from the organoid cultures, they, like the cells of the primary epithelium, exhibit the ability to spontaneous transformation into mesenchymal cells and simultaneously produce CKs and vimentin. Our data suggest that in primary and organoid PG cultures, stromal cells can be formed from epithelium due to the epithelial-to-mesenchymal transition (EMT). The tendency of PG epithelium toward spontaneous EMT may contribute to the mechanism of high sensitivity of prostate tissue to malignant transformation and metastasis. Understanding this mechanism may contribute to the development of effective antitumor therapy of prostate cancer.
\end{abstract}

Keywords: organoid, primary stromal and epithelial cultures of the human prostate, epithelial-to-mesenchymal transition, prostate cancer

DOI: $10.1134 / \mathrm{S} 1990519 \mathrm{X} 21060080$

\section{INTRODUCTION}

The prostate gland $(\mathrm{PG})$ is a small organ in the male reproductive system that has moved into the focus of attention of biologists and physicians in the last decade due to its leading role in morbidity and mortality from prostate cancer (PC) (Siegel et al., 2018). The PG has turned out to be significantly more sensitive to oncogenic transformation than other genital organs. PC is diagnosed in one out of every seven men in the course of his life (Siegel et al., 2016). The PG is glandular organ. Its development and functions 
are regulated by the action of androgens on tissue-specific stromal and epithelial cells (Prins and Putz, 2008). Stromal cells in the PG are mainly smooth muscle cells. Their number is twice the number of epithelial cells, which is associated with the pumping function of the organ, periodically ejecting secreted fluid (Bartsch and Rohr, 1980).

There are two main types of PG epithelial cellsbasal and luminal-which differ in markers. Basal cells are located on the basement membrane and form the basement layer of PG epithelial structures. These cells produce cytokeratins (CKs) 5 and 14 (Brawer et al., 1985 ) and the p63 transcription factor of the p53 family (Signerotti et al., 2000). The main type of PG epithelial cells are luminal cells that express the androgen receptor (AR), low-molecular-weight CK8 and CK18 (Abate-Shen and Shen, 2000). In the process of differentiation, basal cells turn into luminal cells. A small population of PG basal cells has been identified as stem cells (SCs) in human and mice. These cells express tumor associated calcium signal transducer 2 (TROP2), p63, and CD133 (Goldstein et al., 2008; Trerotola et al., 2010).

PC, like cancer in other organs, arises from tumor SCs (TSCs), which form a small population of cells in tumor tissue, and, nevertheless, exhibit the basic properties of progression, invasion, metastasis, and resistance to anticancer therapy (Bao et al., 2006; Li et al., 2008). The progenitor cells of PC (cells of origin) are the cells within the tumor tissue that serve as targets for cancer transformation (Visvader, 2011). Such cells differ from TSCs. Their key feature is tumor regeneration (Clevers, 2011).

Target cells in PC can be both basal and luminal cells, but phenotypically PC cells are luminal and carry AR (Xin, 2013). Treatment of primary PCs is based on androgen deprivation therapy against ARbearing cancer cells. Such therapy is successful during the first 16-20 months, but, then, the PC inevitably switches into a progressive metastatic form, so-called "castration-resistant PC" (CRPC), which is resistant to antiandrogen therapy (Fizazi et al., 2019; Elbadawy et al., 2020). Determining the mechanism of CRPC and finding an effective therapy thereof are urgent biomedical issues that can be resolved using modern preclinical models.

Currently, there are two effective preclinical models of PC: human tumor xenografts to immunodeficient mice (patient derived xenografts, PDX), and organoid cultures of human PC (patient derived organoids, PDO) (Bleijs et al., 2019). In both models, human tumor cells retain their molecular-genetic

Abbreviations: BSA-bovine serum albumin, CRPC-castration-resistant prostate cancer, RT-room temperature, OCorganoid culture, $\mathrm{OC}-\mathrm{PC}-$ organoid culture of human $\mathrm{PC}$, TSC-tumor stem cell, RT-PCR-reverse transcription polymerase chain reaction, $\mathrm{PG}-$ prostate gland, $\mathrm{PC}-$ prostate cancer, SC-stem cells, CK-cytokeratin, EMT-epithelial-tomesenchymal, AR-androgen receptor. properties for a long time, but the PDX technology is limited by the need to use immunodeficient mouse strains. OC-PC, in contrast to PDX, can be used for rapid drug screening to develop personalized therapy. The technology of OC-PC was developed in the last decade. Its application is based to generate $3 \mathrm{D}$ cultures of cells that arise from SCs and maintain all the properties of the maternal tissue (Sato et al., 2009). OCs can be formed from both normal and tumor tissue (Sato et al., 2011). The first publications about OCPC appeared in 2014 (Karthaus et al., 2014; Gao et al., 2014). OC-PG can be obtained from normal or tumor epithelial cells. It maintains, for at least an year, all the properties of the original tissue during the assessment of its molecular, histological, tissue, and genetic profiles. Using $\mathrm{OC}-\mathrm{PC}$, it has already been possible to model rare PC phenotypes (Puca et al., 2018).

The mechanism of high sensitivity of the PG to malignant transformation and generation of progenitor cells can be hidden in the interaction and formation of PG stromal and epithelial cells, which are manifested during the formation of primary cultures, including $\mathrm{OC}-\mathrm{PG}$.

The aim of this work was to obtain primary stromal, epithelial, and organoid cultures from the human $\mathrm{PG}$ and marker analysis of $\mathrm{OC}-\mathrm{PG}$ obtained from tumor and normal PG tissue.

\section{MATERIALS AND METHODS Prostate Tissue Samples}

PG samples were obtained from patients who had undergone radical prostatectomy for prostate cancer at the Urology Department of the Second City Clinical Hospital in St.Petersburg in accordance with the protocol of the ethical committee of this hospital. PG samples of about $100 \mathrm{mg}$ in weight containing a tumor node and normal tissue of the same layer were placed in tubes with $5 \mathrm{~mL}$ of sterile saline solution containing $50 \mu \mathrm{g} / \mathrm{mL}$ gentamicin (Biolot, Russia). Each of two samples was divided with sharp scissors into three parts. One part was fixed in $10 \mathrm{~mL}$ of $4 \%$ paraformaldehyde (Sigma, United States) in a phosphate buffer ( $\mathrm{pH}$ 7.4) for subsequent histological processing. The second sample was intended for the extraction of total RNA and total cell proteins. The third part was treated with collagenase to prepare a cell suspension, which was subsequently used to obtain organoid, stromal, and epithelial cultures.

\section{Establishment of Primary Stromal and Epithelial Cell Cultures from PG Samples}

PG samples intended for obtaining cell cultures were placed in $10-\mathrm{cm}$ Petri dishes in $10 \mathrm{~mL}$ of sterile phosphate buffer (PBS), cut with sterile scissors into $1 \mathrm{~mm}$ pieces, transferred into $15-\mathrm{mL}$ conical plastic tubes (TTP, Novosibirsk, Russia), and subjected to 
enzymatic treatment in $1 \mathrm{~mL}$ of a solution containing $5 \mathrm{mg}$ of type II collagenase (Life Technologies, United States) in $1 \mathrm{~mL}$ of adDMEM/F12 medium (advanced) containing $50 \mu \mathrm{g} / \mathrm{mL}$ of penicillin and streptomycin, $10 \mathrm{mM}$ of HEPES, and GlutaMAX (adDMEM/F12+++; Life Technologies, United States), Y27632 Rho-kinase inhibitor (Abmole Bioscience, United States) at a final concentration of $10 \mu \mathrm{M}$, and dehydrotestosterone (Sigma, United States) at a final concentration of $1 \mathrm{nM}$ (Drost et al., 2016). The tubes were incubated on a PST-60 HL-4 rotary shaker (Biosan, Latvia) at $230 \mathrm{rpm}$ for $18 \mathrm{~h}$ at $37^{\circ} \mathrm{C}$. Then the suspension was centrifuged at $250 \mathrm{~g}$ for $5 \mathrm{~min}$. The cell pellet was washed in $5 \mathrm{~mL}$ of adDMEM/F12 medium, filtered through a nylon sieve with $70-\mu \mathrm{m}$ pores (Corning, United States), and precipitated at $250 \mathrm{~g}$ for $5 \mathrm{~min}$. The pellet was resuspended in $1 \mathrm{~mL}$ of TrypLE Express solution (Life Technologies, United States) and incubated for $1 \mathrm{~h}$ on a PST-60 HL-4 rotary shaker (Biosan, Latvia) at $230 \mathrm{rpm}$ and $37^{\circ} \mathrm{C}$. Five milliliters of adDMEM/F12 medium was added to the suspension. The cells were pelleted by centrifugation at $250 \mathrm{~g}$ for $5 \mathrm{~min}$, and the pellet was resuspended in $500 \mu \mathrm{L}$ of adDMEM/F12+++ medium. To count the cell number, $5 \mu \mathrm{L}$ of the cell suspension was mixed with $45 \mu \mathrm{L}$ of $1 \%$ acetic acid and $50 \mu \mathrm{L}$ of $2 \%$ trypan blue (Biolot, Russia). The cells were counted in a Goryaev's chamber.

To obtain primary stromal cultures, $2 \times 10^{4}$ cells from the cell suspension were added to $4 \mathrm{~mL}$ of SCBM medium (Lonza, Switzerland) specific for human PG stromal cells and plated into $60-\mathrm{mm}$ culture dishes (TPP, Novosibirsk, Russia). To obtain epithelial cell cultures, $2 \times 10^{4} \mathrm{PG}$ cells obtained after sample treatment with collagenase were resuspended in $4 \mathrm{~mL}$ of PrEBM medium (Lonza, Switzerland) specific for human PG epithelial cells and plated on $60-\mathrm{mm}$ culture dishes precoated with collagen (Biolot, Russia). Images of stromal, epithelial, and organoid cultures were obtained without reseeding cells at 1-4 weeks of cultivation using an Axiovert 200M microscope (Germany) and a DFC420 camera (Leica, Germany) in transmitted light or phase contrast mode. A $20 \times / 0.5$ objective was used, with the image size being $1728 \times$ 1296 pixels.

\section{Obtaining, Cultivation, and Subculturing of OC from Tumor and Normal Tissue PG}

Cells $\left(1 \times 10^{5}\right)$ obtained after sample treatment with collagenase were resuspended on ice in $20 \mu \mathrm{L}$ of adDMEM/F12+++ medium, mixed with $140 \mu \mathrm{L}$ of Matrigel preliminarily melted on ice (BD, United States). $40 \mu \mathrm{L}$ of Matrigel were placed into each of four wells of a 24-well culture plate (Corning, United States). After applying the Matrigel, the plate was turned over and placed in a $\mathrm{CO}_{2}$ incubator for $15 \mathrm{~min}$.
Five hundred $\mu \mathrm{L}$ of medium for the cultivation of PG organoids of the following composition was added to each well: $1.0 \mathrm{~mL}$ of B27 (Life Technologies, United States), $500 \mu \mathrm{L}$ of $1 \mathrm{M}$ nicotinamide in PBS (Sigma, United States), $125.0 \mu \mathrm{L}$ of $500 \mathrm{mM} N$-acetylcysteine (Sigma, United States), $0.5 \mu \mathrm{L}$ of EGF solution $(0.5 \mathrm{mg} / \mathrm{mL}$ in PBS + 0.1\% BSA) (PeproTech, United States), $5 \mu \mathrm{L}$ of $5 \mathrm{mM}$ A83-01 in DMSO (Tocris Bioscience, United States), $50 \mu \mathrm{L}$ of Noggin $(100 \mu \mathrm{g} / \mathrm{mL}$ in PBS $+0.1 \%$ BSA) (PeproTech, United States), $50 \mu \mathrm{L}$ of R-spondin 1 solution $(500 \mu \mathrm{g} / \mathrm{mL}$ in PBS + $0.1 \%$ BSA) (R\&D Systems, United States), $50 \mu \mathrm{L}$ of $1 \mu \mathrm{M}$ dehydrotestosterone in ethanol (Sigma, United States), $5 \mu \mathrm{L}$ of FGF2 solution $(50 \mu \mathrm{g} / \mathrm{mL}$ in PBS + $0.1 \%$ BSA) (PeproTech, United States), $5 \mu \mathrm{L}$ of FGF10 solution $(0.1 \mathrm{mg} / \mathrm{mL}$ in PBS $+0.1 \%$ BSA $)$ (PeproTech, United States), $5 \mu \mathrm{L}$ of $10 \mathrm{mM}$ of E2 prostaglandin in DMSO (Tocris Bioscience, United States), $16.7 \mu \mathrm{L}$ of $30 \mathrm{mM} \mathrm{SB} 202190$ in DMSO (Sigma, United States), and up to $50 \mathrm{~mL}$ of adDMEM/F12+++ (Life Technologies, United States).

\section{Organoid Passing}

At the beginning of organoid cultivation, $5 \mu \mathrm{L}$ of $100 \mathrm{mM} 27632$ reagent (Abmole Bioscience, United States) were added to the culture medium (Drost et al., 2016). After 14 days, organoids from one well of a 24-well plate were suspended in their own culture medium, transferred into a $15-\mathrm{mL}$ plastic tube, and precipitated by centrifugation for $5 \mathrm{~min}$ at $250 \mathrm{~g}$. The pellet was resuspended in $1 \mathrm{~mL}$ TrypLE with $10 \mu \mathrm{M}$ Y-27632 and the tube was placed on an orbital shaker for $5 \mathrm{~min}$ at $37^{\circ} \mathrm{C}$. TrypLE was inactivated by adding adDMEM/F12+++ medium containing 5\% FBS and centrifuged at $200 \mathrm{~g}$ for $5 \mathrm{~min}$. The supernatant was removed, and the cell pellet was resuspended in $80 \mu \mathrm{L}$ of Matrigel. An amount of $40 \mu \mathrm{L}$ of Matrigel with cells was placed in the center of a well of a 24-well plate. The plate was transferred in the inverted state in a $\mathrm{CO}_{2}$ incubator for $15 \mathrm{~min}$ and added to wells of 500 $\mu \mathrm{L}$ of medium for organoids containing $10 \mu \mathrm{M}$ of $\mathrm{Y}$ 27632 Rho-kinase inhibitor. The medium was exchanged every 2-3 days (Drost et al., 2016).

\section{Staining of PG Tissue Sections with Hematoxylin/Eosin}

Tissue samples were fixed in $4 \%$ buffered paraformaldehyde (pH 7.4) for 40-48 h, washed with running water, dehydrated with isopropanol, and embedded in paraffin. Paraffin tissue sections with a thickness of $2.5 \mu \mathrm{m}$ were dewaxed with xylene, rehydrated with isopropanol, and stained with hematoxylin/eosin in a conventional manner. After dehydration and clarification in xylene, the stained sections were embedded in a microscopic medium. 
Table 1. Primers used to amplify markers in PG tissue and organoid culture derivatives

\begin{tabular}{l|l|l|c}
\hline \multicolumn{1}{c|}{ Gene } & \multicolumn{1}{|c|}{ Primer forward $\left(5^{\prime}-3^{\prime}\right)$} & \multicolumn{1}{c}{ Primer reverse $\left(5^{\prime}-3^{\prime}\right)$} & Amplicon size, bp \\
\hline$C K 5$ & AAGCTGCTGGAGGGCGAGGAATG & CGGGAGGAGGAGGTGGTGGAGAC & 341 \\
$T P 63$ & TCCTCAGGGAGCTGTTATCC & ATTCACGGCTCAGCTCATGG & 101 \\
$C K 18$ & TGGTCACCACACAGTCTGCT & CCAAGGCATCACCAAGATTA & 348 \\
$A R 1$ & AAGACGCTTCTACCAGCTCACCAA & TCCCAGAAAGGATCTTCGCACTT & 170 \\
$A M A C R$ & TGGCCACGATATCAACTATTTGG & ACTCAATTTCTGAGTTTTCCACAGAA & 247 \\
GAPDH & CCATCTTCCAGGAGCGAGA & GGCAGTGATGGCATGGACTGT & 326 \\
\hline
\end{tabular}

Extraction of Total RNA from Patient PG Tissues and Organoid Derivates, as well as cDNA Synthesis

PG tissue samples $2 \times 2 \mathrm{~mm}$ in size were placed in a steel mortar, cooled with liquid nitrogen, and ground with a pestle. The resulting powder was transferred into a separate tube, supplemented with $1 \mathrm{~mL}$ of Trizol (Invitrogen, United States), and left on ice for $5 \mathrm{~min}$. Then, $200 \mu \mathrm{L}$ of cooled chloroform were added to each tube and the suspension was vortexed. After that, the tubes were placed on ice for $3 \mathrm{~min}$ and centrifuged for $15 \mathrm{~min}$ at $4^{\circ} \mathrm{C}$ and $13000 \mathrm{~g}$. The upper phase of the supernatant was transferred into new tubes, and 500 $\mu \mathrm{L}$ of isopropanol (Sigma, United States) was added. It was incubated on ice for $10 \mathrm{~min}$ and, then, centrifuged for $10 \mathrm{~min}$ at $4^{\circ} \mathrm{C}$ and $13000 \mathrm{~g}$. The supernatant was removed, $1 \mathrm{~mL}$ of $70 \%$ ethanol was added, and it was centrifuged for $5 \mathrm{~min}$ at $4^{\circ} \mathrm{C}$ and $7600 \mathrm{~g}$. The supernatant was completely removed, the precipitate was dried at RT for $10 \mathrm{~min}$, dissolved in $32 \mu \mathrm{L}$ of nuclease-free water (Thermo Fisher Scientific, United States), and incubated for $15 \mathrm{~min}$ at $57.5^{\circ} \mathrm{C}$. The RNA concentration was measured on a NanoDrop ND-1000 spectrophotometer (Thermo Fisher Scientific, United States).

The total RNA was isolated from $\mathrm{OC}-\mathrm{PG}$ at the third passage. To obtain RNA, the culture medium was removed from four wells of 24-well plates in which OC was grown. Matrigel was resuspended in each well by pipetting in $1 \mathrm{~mL}$ of PBS. The suspension was collected in a $15-\mathrm{mL}$ tube and centrifuged for $5 \mathrm{~min}$ at $300 \mathrm{~g}$. An amount of $750 \mu \mathrm{L}$ of Trizol (Invitrogen, United States) was added to the sediment and pipetted ten times until the sediment was completely dissolved. The tubes were left on ice for $5 \mathrm{~min}$, then, $150 \mu \mathrm{L}$ of cooled chloroform was added to each tube, vortexed, left on ice for $5 \mathrm{~min}$, and centrifuged for $15 \mathrm{~min}$ at $4^{\circ} \mathrm{C}$ and $13000 \mathrm{~g}$. After centrifugation, the upper phase of the supernatant was transferred to new tubes and $500 \mu \mathrm{L}$ of isopropanol (Sigma, United States) was added. It was incubated on ice for $10 \mathrm{~min}$ and centrifuged for $10 \mathrm{~min}$ at $4^{\circ} \mathrm{C}$ and $13000 \mathrm{~g}$. The supernatant was removed, $1 \mathrm{~mL}$ of $70 \%$ ethyl alcohol was added to the sediment, and it was centrifuged again for $5 \mathrm{~min}$ at $4^{\circ} \mathrm{C}$ and $7600 \mathrm{~g}$. The supernatant was completely removed. The precipitate was dried at RT for $10 \mathrm{~min}$, dissolved in $32 \mu \mathrm{L}$ of nuclease-free water (Thermo
Fisher Scientific, United States), and incubated for $15 \mathrm{~min}$ at $57.5^{\circ} \mathrm{C}$. The RNA concentration was measured on a NanoDrop ND-1000 spectrophotometer (Thermo Fisher Scientific, United States).

To synthesize cDNA, $2 \mu \mathrm{g}$ of RNA was mixed with $1 \mu \mathrm{L}$ of oligo-dT18 primer (Alkor Bio, Russia). The mixture volume was adjusted to $11 \mu \mathrm{L}$, incubated at $70^{\circ} \mathrm{C}$ for $10 \mathrm{~min}$, and cooled. with $2 \mu \mathrm{L}$ of buffer for reverse transcriptase (SibEnzyme, Russia), $2 \mu \mathrm{L}$ of $10 \mathrm{mM}$ dNTP mixture (Beagle, Russia), and $0.5 \mu \mathrm{L}$ of RiboLock ribonuclease inhibitor (Thermo Scientific, United States) being added and incubated for $1 \mathrm{~h}$ at $37^{\circ} \mathrm{C}$. The reaction was stopped by heating to $70^{\circ} \mathrm{C}$ for $10 \mathrm{~min}$.

\section{Reverse Transcription Polymerase Chain Reaction (RT-PCR)}

The mixture of reagents for PCR included $1 \mu \mathrm{L}$ of $10 \mathrm{mM}$ dNTP mixture (Beagle, Russia), as well as $2.5 \mu \mathrm{L}$ of tenfold buffer for Taq polymerase, $2.5 \mu \mathrm{L}$ of $10 \mathrm{mM} \mathrm{MgCl} 2,1 \mu \mathrm{M}$ of forward and reverse primers, $2 \mu \mathrm{L}$ of DNA, and $0.25 \mu \mathrm{L}$ of Taq-polymerase (Alkor Bio, Russia) and water up to $25 \mu \mathrm{L}$ of the total volume of the reaction mixture. The mixture was prepared at the temperature of melting ice. Amplification was carried out on a Bio-Rad T100 thermal cycler (United States) at the following temperature regime: initiating melting, $1 \mathrm{~min}, 94^{\circ} \mathrm{C}$; melting, $15 \mathrm{~s}, 94^{\circ} \mathrm{C}$; annealing, $30 \mathrm{~s}, 58^{\circ} \mathrm{C}$; elongation, $30 \mathrm{~s}, 72^{\circ} \mathrm{C}$ ( 40 cycles); plateau, $10 \mathrm{~min}, 72^{\circ} \mathrm{C}$. For primers to the $C K 5$ gene, the annealing temperature was $60^{\circ} \mathrm{C}$. PCR amplification products were subjected to electrophoresis in $2 \%$ agarose gel with ethidium bromide, and the size of individual amplicons in the agarose gel was determined by comparing their mobility with 100-bp markers (Invitrogen, United States) on images obtained using a BioRad ChemiDoc XRS+ (United States) (Table 1).

\section{Immunofluorescent Staining}

Coverslips with cells spread out during growth in culture were transferred into $35-\mathrm{mm}$ dishes, washed once with SPB for $5 \mathrm{~min}$, fixed with $4 \%$ paraformaldehyde for $15 \mathrm{~min}$ and then with $70 \%$ ethyl acetate alcohol overnight at $4^{\circ} \mathrm{C}$, treated with $0.2 \%$ Triton X-100 for $10 \mathrm{~min}$, and washed with PBS twice for $5 \mathrm{~min}$. 
Nonspecific binding of antibodies was blocked for $1 \mathrm{~h}$ with a solution containing 3\% BSA and $0.1 \%$ Tween 20. Then, specific antibodies (dilution 50200) were applied to the cells in a blocking solution for $1 \mathrm{~h}$ at RT. In the case of staining the preparation with two different first antibodies (for example, against CK and vimentin), rabbit antibodies to cytokeratins were first applied for $2 \mathrm{~h}$ at RT and washed three times for 5 min with PBS; mouse antibodies against vimentin were then applied for $2 \mathrm{~h}$ in RT. The slides were then washed three times for 5 min with PBS, and a mixture of second antibodies against rabbit IgG conjugated with $\mathrm{Cy} 5$ and against mouse IgG conjugated with $\mathrm{Cy} 3$ was applied for $1 \mathrm{~h}$ at RT. The slides with cells were then washed three times for $5 \mathrm{~min}$ with PBS and embedded in Anti-Fade medium (BioRad, United States), which reduced nonspecific fluorescence and contained DAPI dye for DNA staining. Immunofluorescence images were obtained on a Leica scanning microscope (Carl Zeiss, Germany) using lasers with a wavelength of 405,543 , and $633 \mathrm{~nm}$ and a $63 \times$ objective.

\section{Antibodies}

The following antibodies were used for immunofluorescence: rabbit anti-PanCK (Thermo Fisher Scientific, United States), mouse anti-vimentin (Sigma, United States), and mouse monoclonal antibodies against AMACR (Popov et al., 2018). Goat antibodies against mouse $\operatorname{IgG}(\mathrm{H}+\mathrm{L})$ conjugated with $\mathrm{Cy} 3$ cyanine dye and goat antibodies against rabbit $\mathrm{IgG}$ conjugated with Cy5 (Molecular Probes, Thermo Fisher Scientific, United States) served as second antibodies for immunofluorescence. For immunoblotting, anti-rabbit antibodies conjugated to horseradish peroxidase (HRP; Cell Signaling, United States) and anti-mouse antibodies conjugated to HRP (BioRad, United States) were used.

\section{RESULTS}

\section{Morphological Changes of PG Tissue in Patients with Prostate Cancer}

PG tissue samples taken from a tumor and surrounding normal tissue during surgery were subjected to histological analysis after fixation and staining with hematoxylin/eosin, followed by transmitted light microscopy. In normal PG tissue, microscopy revealed alveolar-tubular epithelial glands in longitudinal and cross sections separated by layers of connective tissue (Fig. 1I, a). In tumor samples, hyperplasia of the glandular tissue of PG is worthy of note. It was manifested in a significantly increased number of small and medium glands with small internal lumens and narrow layers of connective tissue separating them (Fig. 1I, b). In the tumor tissue, the gland structure was disrupted. The basal cell layer was practically absent, and the cells of the luminal layer lost their columnar shape (Fig. 1I, b).

\section{Characterization of Primary Cell Cultures Obtained from $P G$ Tissue}

Primary cultures from normal or tumor human PG tissue growing in a special SCBM medium (Lonza, Switzerland) for PG stromal cells began to form in the second week of cultivation and were represented by epithelial cells. Such cells had a polygonal shape, were in close contact with each other, and formed clusters that increased in size as they grew (Fig. 1II, a). At the third week of cultivation, we observed the appearance in primary cultures of spindle-shaped fibroblast-like cells growing separately (Fig. 1II, b) and gradually forming clones, which increased in size during cultivation until the population of stromal cells became homogeneous. This coincided with a decrease in the number and the gradual complete disappearance of epithelial cells.

\section{Cell Markers in Primary Stromal Cultures of Human PG Tissue}

Cells of primary PG cultures were stained with antibodies to epithelial and stromal markers, as well as the prostate cancer marker AMACR. We used CKs as epithelial markers, which were detected by antibodies that recognize the same epitope in several CKs (PanCK), and vimentin as a stromal marker. Polygonal cells closely located by each other, forming clusters at the beginning of cultivation of the cell suspension from PG, were stained with antibodies to PanCK (Fig. 1III, a). Fibroblast-like cells growing separately and gradually becoming the dominant population in prostate stromal cultures were stained for vimentin (Fig. 1III, b). At the same time, with simultaneous staining with antibodies to PanCK and vimentin, after $2-3$ weeks of cultivation, cells that produced both CKs and vimentin were detected in primary cultures (Fig. 1III, c). To identify cells originating from prostate tumor tissue, we stained primary cultures with antibodies to AMACR. This marker was absent in the epithelial cells of the primary PG cultures originating from non-PG tumor tissue (Fig. 1III, d), but it was clearly defined in the epithelial cells of the primary cultures originating from the tumor tissue (Fig. 1III, e).

\section{OCs from Normal and Tumor PG Tissue}

Organoids in 3D cultures of PG appeared already on the third day of cultivation. Their number in Matrigel significantly increased by the seventh day of cultivation (Fig. $2 I$, a), and, by the 14 th day, their size and number had increased even more (Fig. 2I, b). They were passaged $1: 4$ in the same format. 

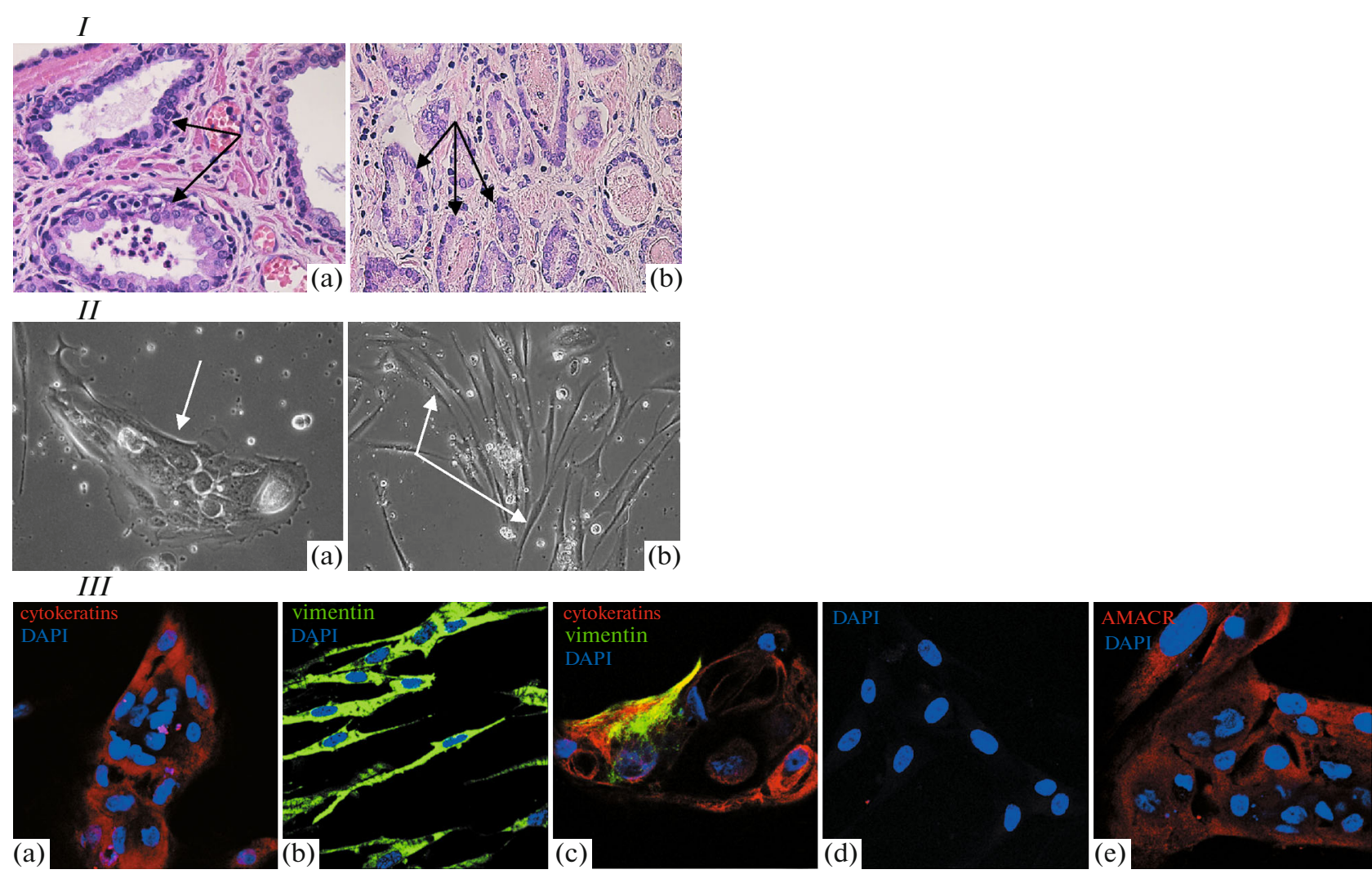

Fig. 1. Functionally different markers in tumor and normal prostate tissue in patients with a PG tumor. (I) Histological preparations of (a) normal and (b) tumor-bearing PG. Staining with hematoxylin-eosin. Arrows show the epithelial structures of PG. Images were captured with an Axiovert 200M microscope (Germany) and a DFC420 camera (Leica, Germany) in transmitted light, image size $1728 \times 1296$ pixels, ob. $20 \times$. (II) (a) Epithelial and (b) stromal cells in primary stromal PG cultures. Arrows show (a) epithelial and (b) stromal cells. Images were captured on the same microscope in the phase contrast mode, image size $1728 \times$ 1296 pixels, ob. 20×. (III) Markers in primary stromal PG cultures, images obtained by staining with antibodies to (a) cytokeratins (PanCK), (b) vimentin, (c) cytokeratins and vimentin combined, to AMACR in stromal culture from (d) normal and (e) tumor tissue are shown; nuclei are stained with DAPI (blue); immunofluorescence images were captured with a Leica scanning confocal microscope (Carl Zeiss, Germany) with lasers with wavelengths of 405, 543, and $633 \mathrm{~nm}$, image size $1024 \times 1024$ pixels, ob. $63 \times$.

In some OCs, growth of epithelial cells was detected (Fig. 2I, c). Such cells, like the primary epithelium in stromal cultures, were positive when stained with antibodies to PanCK when transferred to 60-mm Petri dishes and passaged. Passaging with subsequent staining of such cell cultures with antibodies to PanCK and vimentin revealed in immunofluorescence the production of CKs and vimentin in the same cells (Fig. 2I, d).

\section{Marker Characterization of Tissues and $O C-P G$ Using $R T-P C R$}

To confirm the identity of normal tumor tissue in PG and OC derivatives, we assessed the expression of genes for markers of the basal $(C K 5, p 63)$ and luminal $(C K 18, A R)$ epithelium of $\mathrm{PG}$, as well as $A M A C R$ gene, a marker of prostate cancer. As a control, the expression of GAPDH gene was probed by RT-PCR. In PG tissue samples obtained from ten patients and derived organoids, markers of basal and luminal epithelial PG cells were always detected in the same cultures. This was equally true for organoids derived from normal and tumor tissues. In tumor tissue and derived organoids, AMACR was present. It was not detected in PG normal tissue and derived organoids (Fig. 2II).

\section{DISCUSSION}

In this work, we found that, unlike the rapid emergence of a homogeneous population of mesenchymal cells in primary stromal cultures of most tissues, for example, of bone marrow, adipose tissue, endometrium, the heart, and the urinary bladder (Popov et al., 2007; Musina et al., 2008; Meirelles and Nardi, 2009; Zhidkova et al., 2013; Mikheeva et al., 2018), stromal cell cultures of the human PG exhibit different properties. In stromal PG cultures, cells appear at the second week of cultivation and are epithelial cells that produce CKs. A homogeneous population of mesen- 

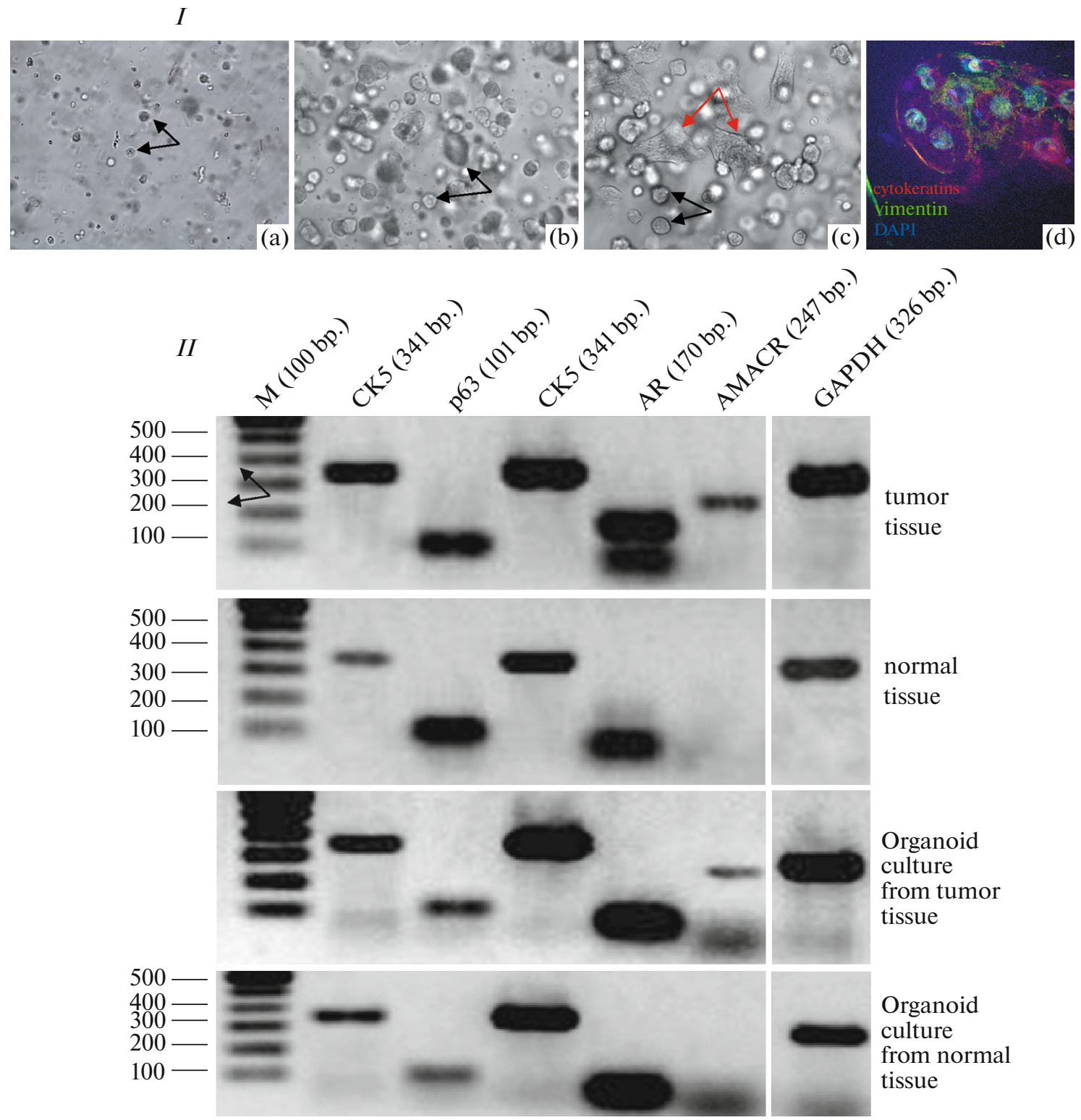

Fig. 2. Marker characteristics of organoid cultures derived from $(I)$ normal and $(I I)$ tumor-bearing. (I) Cultivation for (a) 7 and (b-c) 14 days. Black arrows mark organoids; red arrows mark epithelial cells; images were captured with the same microscope as in Fig. 1a in transmitted light, ob. 20×. (d) Immunofluorescence of cytokeratins (red) and vimentin (green) in epithelial cells derived from $\mathrm{OC}-\mathrm{PG}$ and stained with specific antibodies; nuclei are colored with DAPI (blue); images were obtained with a scanning microscope (Carl Zeiss, Germany) with lasers with a wavelength of 405, 543, and $633 \mathrm{~nm}$, ob. 63×. (II) Electrophoretic images of RT-PCR amplification products, markers of basal (CK5, p63) and luminal (CK18, AR) epithelium, as well as AMACR in normal and tumor tissues of PG and in OC derivatives. Comparison marker protein (M) is $100 \mathrm{bp}$.

chymal cells producing vimentin forms only by the end of the fourth week of cultivation, that is accompanied by the disappearance of epithelial cells.

Our observations are confirmed by publications from other laboratories. It has been noted that explants of human PG initially produce cells with epithelial morphology, while stromal cells appear in culture after 21 days of cultivation (Janssen et al., 2000). In a publication from another laboratory, the authors used a suspension of PG cells. In the primary culture, the presence of epithelial markers was first observed, with the culture becoming homogeneous-like fibroblast cells producing vimentin only at the fifth passage (Gravina et al., 2013). The rapid generation of a homogeneous population of mesenchymal cells in primary stromal cultures of most tissues is probably related to their origin from the primary mesenchyme rather than from tissue-specific SCs (Sági et al., 2012). Conversely, the lag in the production of mesenchymal cells in primary cultures of the PG indicate their origin 
from another source, for example, from epithelial cells of the PG, which are formed at the beginning of cultivation in primary PG cultures. The results of our work suggest that the change in the epithelial cell profile to a mesenchymal one in primary cultures of the human PG can occur as a result of the epithelial-mesenchymal transition (EMT).

This hypothesis is confirmed by the observation that in primary stromal cultures of human PG some cells simultaneously produce both epithelial (CKs) and a stromal (vimentin) markers. This observation is also proved by the results of cultivation of PG organoids derived from tissue-specific SCs. PG organoids during cultivation often show concomitant growth of epithelial cells, but never form stromal cells. However, subsequent cultivation of the epithelium obtained from the organoid PG cultures revealed (using immunofluorescence) in individual cells the simultaneous production of cytokeratins and vimentin (Fig. 2I, d), as is observed in primary PG cultures (Fig. 1III, c).

It is known, that EMT and the opposite mesenchymal-epithelial transition (MET) are physiological processes that an organism uses during development, regeneration, and regulation of SC properties. The EMT is also involved in the formation of fibrosis, inflammation, invasion, and metastasis (Zhang and Weinberg, 2018). On the other hand, the ability to invade and metastasize is known to differ significantly in different tissues, which may be associated with the signaling pathways and mesenchymal-epithelial interactions that regulate epithelial growth (Grant and Kyprianou, 2013). The tendency of the PG epithelium to malignant transformation and the development of CRPC can be based on the signal regulation, which is carried out by androgens. Androgen deprivation therapy for PC inevitably ends with AR receptor mutations and restoration of androgen signaling along collateral pathways or reprogramming of cells of primary PC and the emergence of CRPC, which is resistant to androgen deprivation therapy. Subsequent study of the EMT mechanism in PG cells will make it possible to understand the mechanism of their sensitivity to cancer transformation and to develop effective methods of therapy.

\section{ACKNOWLEDGMENTS}

The authors are grateful to the staff of the Collective Microscopy Center of the Institute of Cytology, Russian Academy of Sciences, for their help in assessing the immunofluorescent staining of cells.

\section{FUNDING}

This work was carried out within the framework of the budget theme of the Institute of Cytology of the Russian Academy of Sciences (no. 0124-2019-0004) and supported by an internal grant from the Institute of Cytology.

\section{COMPLIANCE WITH ETHICAL STANDARDS}

Conflict of interest. The authors declare that they have no conflict of interest.

Statement of compliance with standards of research involving humans as subjects. Samples of prostate tissue were obtained from patients who had undergone radical prostatectomy for prostate cancer in the Urology Department of the Second City Clinical Hospital of St.Petersburg in accordance with the protocol of the ethical committee of this hospital and with informed patient consent. The authors did not conduct experiments with animals.

\section{OPEN ACCESS}

This article is licensed under a Creative Commons Attribution 4.0 International License, which permits use, sharing, adaptation, distribution and reproduction in any medium or format, as long as you give appropriate credit to the original author(s) and the source, provide a link to the Creative Commons license, and indicate if changes were made. The images or other third party material in this article are included in the article's Creative Commons license, unless indicated otherwise in a credit line to the material. If material is not included in the article's Creative Commons license and your intended use is not permitted by statutory regulation or exceeds the permitted use, you will need to obtain permission directly from the copyright holder. To view a copy of this license, visit http://creativecommons.org/licenses/by/4.0/.

\section{REFERENCES}

Abate-Shen, C. and Shen, M.M., Molecular genetics of prostate cancer, Genes Dev., 2000, vol. 14, p. 2410.

Bao, S., Wu, Q., McLendon, R.E., Hao, Y., Shi, Q., Hjelmeland, A.B., Dewhirst, M.W., Bigner, D.D., and Rich, J.N., Glioma stem cells promote radioresistance by preferential activation of the DNA damage response, $\mathrm{Na}$ ture, 2006, vol. 444, p. 756.

Bartsch, G. and Rohr, H.P., Comparative light and electron microscopic study of the human, dog and rat prostate. An approach to an experimental model for human benign prostatic hyperplasia (light and electron microscopic analysis) - a review, Urol. Int., 1980, vol. 35, p. 91.

Bleijs, M., van de Wetering, M., Clevers, H., and Drost, J., Xenograft and organoid model systems in cancer research, EMBO J., 2019, vol. 38, e101654.

https://doi.org/10.15252/embj.2019101654

Brawer, M.K., Peehl, D.M., Stamey, T.A., and Bostwick, D.G., Keratin immunoreactivity in the benign and neoplastic human prostate, Cancer Res., 1985, vol. 45, p. 3663.

Clevers, H., The cancer stem cell: premises, promises and challenges, Nat. Med., 2011, vol. 17, p. 313.

Drost, J., Karthaus, W.R., Gao, D., Driehuis, E., Sawyers, C.L., Chen, Y., and Clevers, H., Organoid culture systems for prostate epithelial and cancer tissue, Nat. Protoc., 2016, vol. 11, p. 347.

Elbadawy, M., Abugomaa, A., Yamawaki, H., Usui, T., and Sasaki, K., Development of prostate cancer organoid cul- 
ture models in basic medicine and translational research, Cancers (Basel), 2020, vol. 12, p. 777.

Fizazi, K., Tran, N., Fein, L., Matsubara, N., RodriguezAntolin, A., Alekseev, B.Y., Özgüroğlu, M., Ye, D., Feyerabend, S., Protheroe, A., Sulur, G., Luna, Y., Li, S., Mundle, S., and Chi, K.N., Abiraterone acetate plus prednisone in patients with newly diagnosed high-risk metastatic castration-sensitive prostate cancer (LATITUDE): final overall survival analysis of a randomised, double-blind, phase 3 trial, Lancet Oncol., 2019, vol. 20, p. 686.

Gao, D., Vela, I., Sboner, A., Iaquinta, P.J., Karthaus, W.R., Gopalan, A., Dowling, C., Wanjala, J.N., Undvall, E.A., Arora, V.K., Wongvipat, J., Kossai, M., Ramazanoglu, S., Barboza, L.P., Di, W., Cao, Z., Zhang, Q.F., Sirota, I., Ran, L., MacDonald, T.Y., Beltran, H., Mosquera, J.M., Touijer, K.A., Scardino, P.T., Laudone, V.P., Curtis, K.R., Rathkopf, D.E., Morris, M.J., Danila, D.C., Slovin, S.F., Solomon, S.B., Eastham, J.A., Chi, P., Carver, B., Rubin, M.A., Scher, H.I., Clevers, H., Sawyers, C.L., and Chen, Y., Organoid cultures derived from patients with advanced prostate cancer, Cell, 2014, vol. 159, p. 176.

Goldstein, A.S., Lawson, D.A., Cheng, D., Sun, W., Garraway, I.P., and Witte, O.N., Trop2 identifies a subpopulation of murine and human prostate basal cells with stem cell characteristics, Proc. Natl. Acad. Sci. U. S. A., 2008, vol. 105, p. 20882.

Grant, C.M. and Kyprianou, N., Epithelial mesenchymal transition (EMT) in prostate growth and tumor progression, Transl. Androl. Urol., 2013, vol. 2, p. 202.

Gravina, G.L., Mancini, A., Ranieri, G., Di, Pasquale, B., Marampon, F., Di, Clemente, L., Ricevuto, E., and Festuccia, C., Phenotypic characterization of human prostatic stromal cells in primary cultures derived from human tissue samples, Int. J. Oncol., 2013, vol. 42, p. 2116.

Janssen, M., Albrecht, M., Möschler, O., Renneberg, H., Fritz, B., Aumüller, G., and and, Konrad, L., Cell lineage characteristics of human prostatic stromal cells cultured in vitro, Prostate, 2000, vol. 43, p. 20.

Karthaus, W.R., Iaquinta, P.J., Drost, J., Gracanin, A., van, Boxtel, R., Wongvipat, J., Dowling, C.M., Gao, D., Begthel, H., Sachs, N., Vries, R.G.J., Cuppen, E., Chen, Y., Sawyers, C.L., and Clevers, H.C., Identification of multipotent luminal progenitor cells in human prostate organoid cultures, Cell, 2014, vol. 159, p. 163.

Li, X., Lewis, M.T., Huang, J., Gutierrez, C., Osborne, C.K., Wu, M.F., Hilsenbeck, S.G., Pavlick, A., Zhang, X., Chamness, G.C., Wong, H., Rosen, J., and Chang, J.C., Intrinsic resistance of tumorigenic breast cancer cells to chemotherapy, J. Natl. Cancer. Inst., 2008, vol. 100, p. 672 .

da Meirelles, L.S. and Nardi, N.B., Methodology, biology and clinical applications of mesenchymal stem cells, Front. Biosci._Landmrk, 2009, vol. 14, p. 4281.

Mikheeva, N.F., Butylin, P.A., Zaritskii, A.Yu., and Popov, B.V., A decrease in the proliferative activity of human mesenchymal stem cells during long-term cultivation is not connected with change in their migration properties, Cell Tissue Biol., 2018, vol. 12, p. 197.

Musina, R.A., Belyavski, A.V., Tarusova, O.V., Solovyova, E.V., and Sukhikh, G.T., Endometrial mesenchymal stem cells isolated from the menstrual blood, Bull. Exp. Biol. Med., 2008, vol. 145, p. 539.

Popov, B.V, Serikov, V.B., Petrov, N.S., Izusova, T.V, Gupta, N., and Matthay, M.A., Lung epithelial cells induce endodermal differentiation in mouse mesenchymal bone marrow stem cells by paracrine mechanism, Tissue Eng., 2007, vol. 13, p. 2441.

Popov, B.V., Sutula, G.I., Petrov, N.S., and Yang, X.J., Preparation and characterization of the antibody recognizing AMACR inside its catalytic center, Int. J. Oncol., 2018, vol. 52, p. 547.

Prins, G.S. and Putz, O., Molecular signaling pathways that regulate prostate gland development, Differentiation, 2008, vol. 76, p. 641.

Puca, L., Bareja, R., Prandi, D., Shaw, R., Benelli, M., Karthaus, W.R., Hess, J., Sigouros, M., Donoghue, A., Kossai, M., Gao, D., Cyrta, J., Sailer, V., Vosoughi, A., Pauli, C., Churakova, Y., Cheung, C., Deonarine, L.D., McNary, T.J., Rosati, R., Tagawa, S.T., Nanus, D.M., Mosquera, J.M., Sawyers, C.L., Chen, Y., Inghirami, G., Rao, R.A., Grandori, C., Elemento, O., Sboner, A., Demichelis, F., Rubin, M.A., and Beltran, H., Patient derived organoids to model rare prostate cancer phenotypes, Nat. Commun., 2018, vol. 9, p. 2404.

Sági, B., Maraghechi, P., Urbán, V.S, Hegyi, B., Szigeti, A., Fajka-Boja, R., Kudlik, G., Német, K., Monostori, E., Gócza, E., and Uher, F., Positional identity of murine mesenchymal stem cells resident in different organs is determined in the postsegmentation mesoderm, Stem Cells Dev., 2012, vol. 21, p. 814.

Sato, T, Vries, R.G., Snippert, H.J., van de Wetering, M., Barker, N., Stange, D.E., van Es, J.H., Abo, A., Kujala, P., Peters, P.J., and Clevers, H., Single Lgr5 stem cells build crypt-villus structures in vitro without a mesenchymal niche, Nature, 2009, vol. 459, p. 262.

Sato, T., Stange, D.E., Ferrante, M., Vries, R.G., Van Es, J.H., Van den Brink, S., Van Houdt, W.J., Pronk, A., Van Gorp, J., Siersema, P.D., and Clevers, H., Long-term expansion of epithelial organoids from human colon, adenoma, adenocarcinoma, and Barrett's epithelium, Gastroenterology, 2011, vol. 141, p. 1762.

Siegel, R.L., Miller, K.D., and Jemal, A., Cancer statistics, 2018, CA Cancer J. Clin., 2018, vol. 68, p. 7.

Siegel, R.L., Miller, K.D., and Jemal, A., Cancer statistics, 2016, CA Cancer J. Clin., 2016, vol. 66, p. 7.

Signoretti, S., Waltregny, D., Dilks, J., Isaac, B., Lin, D., Garraway, L., Yang, A., Montironi, R., McKeon, F., and Loda, M., p63 is a prostate basal cell marker and is required for prostate development, Am. J. Pathol., 2000, vol. 157, p. 1769.

Trerotola, M., Rathore, S., Goel, H.L., Li, J., Alberti, S., Piantelli, M., Adams, D., Jiang, Z., and Languino, L.R., CD133, Trop-2 and alpha2beta1 integrin surface receptors as markers of putative human prostate cancer stem cells, Am. J. Transl. Res., 2010, vol. 2, p. 135.

Visvader, J.E., Cells of origin in cancer, Nature, 2011, vol. 469 , p. 314.

Xin, L., Cells of origin for cancer: an updated view from prostate cancer, Oncogene, 2013, vol. 32, p. 3655.

Zhang, Y. and Weinberg, RA., Epithelial-to-mesenchymal transition in cancer: complexity and opportunities, Front. Med., 2018, vol. 12, p. 361.

Zhidkova, O.V., Petrov, N.S., and Popov, B.V., Production and characteristics of the growth and marker properties of mesenchymal stem cells of urinary bladder, $Z$ h. Evol. Biokhim. Fiziol., 2013, vol. 49, p. 67.

Translated by I. Fridlyanskaya 